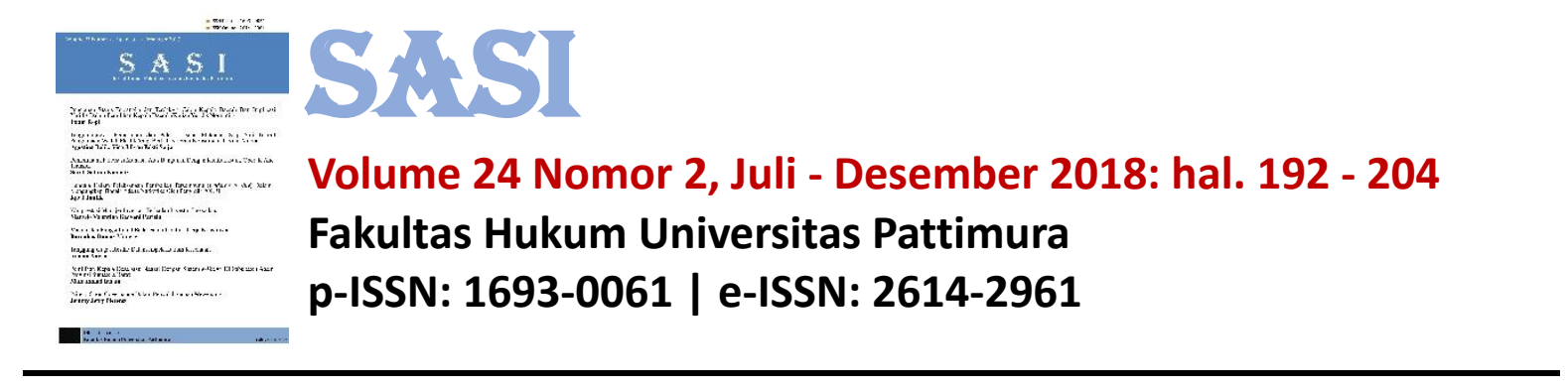

\title{
Penetapan Waktu Pelaksanaan Banding Terhadap Putusan Pengadilan Tata Usaha Negara Pada Daerah Karakteristik Wilayah Kepulauan
}

\author{
Dezonda Rosiana Pattipawae \\ Program Doktor Ilmu Hukum Pascasarjana Universitas Borobudur, Jakarta, Indonesia \\ E-mail: pattipawaeonda@gmail.com
}

\begin{abstract}
The party that makes a legal appeal against the case that has been decided by the State Administrative Court is limited by the time to file an appeal to the High Administrative Court. This as stipulated in the provisions of Article 123 of Act Number 5 of 1986 which stipulates the time for legal appeal against the decision of the State Administrative Court is 14 days after the court decision is notified to him legally

Determination of 14 (fourteen) times to submit an appeal for parties who are dissatisfied or accept the decision of the State Administrative Court as stipulated in the Provisions of Article 123 of Act Number 5 of 1986 which at the time the decision of the State Administrative Court was read out was not present at the hearing stipulated in the provisions of Article 108 paragraph (2) of Law Number 5 of 1986 and residing in an archipelago such as Maluku Province which has a large area and consists of islands, greatly affects the fulfillment of the timeliness determined to file an appeal. It has an impact on the effectiveness of setting 14 (fourteen) days as the deadline for filing an appeal law. Accordingly, based on these conditions, the stipulation of 14 (fourteen) days to file an appeal law is not effectively applied to regions that are characterized by islands. Only effective in areas with continental characteristics.
\end{abstract}

Keywords: Implementation of Appeal, Decision of PTUN, Islands Region

\section{A. PENDAhuluan.}

Negara Indonesia merupakan negara kepulauan (archipelagic state) terbesar di dunia yang terdiri dari sekitar 18.306 pulau besar dan kecil dengan panjang garis pantai kurang lebih 95.181 $\mathrm{km}^{2}$ serta wilayah laut seluas 5,8 juta km2 (termasuk Zona Ekonomi Ekslusif Indonesia). Hal tersebut berkonsekwensi pada diakuinya Negara Republik
Indonesia sebagai negara kepulauan yang ditetapkan dalam ketentuan Pasal 25A Undang-Undang Dasar Negara Republik Indonesia Tahun 1945 yang menyebutkan bahwa Negara Kesatuan Republik Indonesia adalah sebuah negara kepulauan yang berciri nusantara dengan wilayah yang batas-batas dan hak-haknya ditetapkan dengan undang undang. ${ }^{1}$

\footnotetext{
1 Nirahua, Salmon E.M. (2013). Hukum
} 
Terdapat beberapa daerah provinsi yang secara geografis memiliki karakteristik wilayah lautan melebihi luas wilayah daratannya dan terdiri dari gugusan pulau-pulau sehingga daerah-daerah tersebut dikatakan sebagai daerah kepulauan secara umum memiliki karakteristik wilayah yang berbeda dengan daerah yang memiliki karakteristik kontinental. Daerah kepulauan memiliki wilayah laut lebih besar dari wilayah darat sedangkan daerah kontinental memiliki wilayah darat lebih besar dari wilayah laut. Hal ini tentunya berdampak pada rentang kendali pelayanan dan penyelenggaraan pemerintahan dan pembangunan menjadi luas pula. Keadaan ini diperparah oleh kenyataan sulit dijangkau dalam waktu singkat.

Eksistensi Peradilan Tata Usaha Negara melakukan pengawasan terhadap perbuatan pemerintah (administrasi negara) agar dalam melaksanakan fungsinya senantiasa selaras dengan hukum sehingga tidak merugikan hak-hak rakyat. $^{2}$

Menurut Saiyung Pejabat Tata Usaha Negara adalah pelaksana utama pembangunan nasional. Campur tangan pemerintah antara lain dilapangan ekonomi, sosial, politik dan kultur sangat besar. Hal ini dapat menimbulkan akses yang tidak diharapkan. Oleh karena itu perlu diambil langkah hukum melalui lembaga peradilan. ${ }^{3}$

Ketentuan Pasal 116 ayat (1) Undang-Undang Nomor 5 Tahun 1986

Perizinan Pengelolaan Sumber Daya Alam di Wilayah Laut Daerah, Jakarta: Raja Grafindo Persada, h. 3.

2 Tjandra, Riawan. (2009). Peradilan Tata

Usaha Negara Mendorong Terwujudnya Pemerintah Yang Bersih Dan Berwibawa, Yogyakarta: Universitas Adma Jaya, , h. 16.

3 Saiyung, (2000). Mencegah Pejabat Tata Usaha Negara Sebagai Tergugat Dalam PTUN (Analisis Hukum dan Peraturan Perundang-Undangan), Jakarta: Depdagri dan Yayasan Kajian Informasi Perundang-Undangan, h. 55 . sebagaimana telah dirubah terakhir dengan Undang-Undang Nomor 51 Tahun 2009, yang menyebutkan bahwa salinan putusan pengadilan yang telah memperoleh kekuatan hukum tetap, dikirim kepada para pihak dengan surat tercatat oleh panitera pengadilan setempat atas perintah ketua pengadilan yang mengadilinya dalam tingkat pertama selambat-lambatnya dalam waktu empat belas hari. Dalam penjelasan ketentuan Pasal 116 ayat (1) Undang-Undang Nomor 5 Tahun 1986 sebagaimana telah dirubah terakhir dengan Undang-Undang Nomor 51 Tahun 2009 dijelaskan bahwa meskipun putusan pengadilan belum memperoleh kekuatan hukum tetap, para pihak yang berperkara dapat memperoleh salinan putusan yang dibubuhi catatan panitera bahwa putusan tersebut belum memperoleh kekuatan hukum tetap.

Perhitungan waktu empat belas hari untuk dilakukan upaya hukum banding. dihitung sejak putusan dibacakan pada saat persidangan. Apabila perhitungan waktu 14 (empat belas) hari ditetapkan untuk dilakukan upaya hukum banding dihitung sejak putusan tersebut dibacakan, maka pihak yang merasa tidak puas atas putusan tersebut harus melakukan permohonan upaya hukum banding ke Pengadilan Tinggi Tata Usaha Negara paling lambat 14 (empat belas) hari sejak putusan tersebut di ucapkan, hal ini tentunya bagi pemohon yang berdomisili atau bertempat tinggal di daerah yang berkarakteristik kepulauan akan menggalami keterlambatan untuk memenuhi tenggang waktu dimaksud apabila pembacaan putusan tersebut pihak yang akan memohonkan upaya hukum banding tersebut tidak hadir pada saat siding pembacaan putusan. Sebagaimana diketahui bahwa Negara Indonesia adalah Negara kepulauan (arhipelogic state) terbesar di dunia yang terdiri dari sekitar 18. 306 pulau besar dan kecil dengan panjang pantai kurang lebih $95.181 \mathrm{~km}^{2}$ serta wilayah laut seluas 5,8 juta $\mathrm{km}^{2}$ 
(termasuk Zona Ekonomi Eksklusif Indonesia). ${ }^{4}$ Sebagai negara kepulauan, wilayah Negara Republik Indonesia yang terdiri dari pulau-pulau yang terpisahkan oleh laut, namun tetap dalam suatu kesatuan kedaulatan Negara Republik Indonesia.

Kondisi wilayah Negara Indonesia yang dipisahkan oleh laut berkonsekwensi pada akses antar daerah ke daerah lain, termasuk daerah provinsi Maluku yang fisik kewilayahan terdiri dari pulau-pulau, yang mana membutuhkan ketersediaan transportasi untuk menghubungkan daerah yang satu dan daerah yang satu dengan daerah yang lain, terlebih khusus transportasi yang menghubungankan daerah-daerah terpencil dengan daerah-daerah yang menjadi pusat pemerintahan baik pusat pemerintahan daerah provinsi maupun pusat pemerintahan daerah kabupaten/kota dalam provinsi Maluku. Bahkan model transpotasi luat sangat di pengaruhi oleh kondisi alam (musim) yang terjadi di Provinsi Maluku. Hal ini tentunya sangat berdampak juga untuk melakukan upaya hukum banding terhadap Putusan Pengadilan Tata Usaha Negara, yang mana ketika putusan dibacakan dalam persidangan tanpa hadirnya pihak yang akan memohonkan upaya hukum banding terhadap putusan tersebut. Padahal penetepan waktu untuk melakukan upaya hukum banding hanya 14 (empat belas) hari setelah putusan pengadilan itu diberitahukan kepadanya secara sah, yang tentunya berkonsekwensi terhadap keterlembatan waktu bagi pihak pemohon yang bertempat tinggal di daerah yang membutuhkan waktu berhari-hari untuk sampai ke tempat dimana Pengadilan Tata Usaha Negara yang mengeluarkan putusan itu berada untuk melakukan upaya hukum banding.

Dari uraian Pada latar belakang tersebut, maka yang menjadi

4 Retraubun, Alex S. W. dalam Nirahua Salmon E. M. Op. Cit. h. 1. permasalahan dalam tulisan ini adalah : "Apakah penetapan waktu pelaksanaan banding terhadap putusan Pengadilan Tata Usaha Negara pada daerah karakteristik wilayah kepulauan efektif"

\section{B. PEMBAHASAN \\ 1. Penetapan Waktu Pelaksanaan Banding Pada Pengadilan Tinggi Tata Usaha Negara}

Sebagai salah satu pelaku kekuasaan kehakiman yang diberikan kewenangan untuk memeriksa, memutus, dan menyelesaikan sengketa dalam bidang Tata Usaha Negara antara orang atau badan hukum perdata dengan pejabat tata usaha Negara maka Pengadilan Tata Usaha Negara dan Pengadilan Tinggi Tata Usaha Negara yang berpuncak pada Mahkamah Agung berwenang menguji sah tidaknya tindakan badan atau pejabat tata usaha Negara dalam mengeluarkan suatu keputusan tata usaha Negara. Hal ini sebagaimana dijelaskan dalam penjelasan umum Undang-Undang Nomor 5 Tahun 1985 bahwa Pengadilan Tata Usaha Negara merupakan Pengadilan tingkat pertama yang diberikan kewenangan untuk memeriksa, memutus, dan menyelesaikan sengketa Tata Usaha Negara bagi rakyat pencara keadilan. Sedangkan Pengadilan Tinggi Tata Usaha Negara merupakan Pengadilan tingkat banding terhadap sengketa yang telah diputus oleh Pengadilan Tata Usaha Negara, dan Mahkamah Agung sebagai pelaksana tertinggi kekuasaan kehakiman dan pengadilan pada tingkat kasasi.

Oleh karena itu, ketika masyarakat dalam hal ini orang atau badan hukum perdata yang merasa kepentingannya di rugikan akibat tindakan badan atau pejabat tata usaha Negara mengeluarkan suatu keputusan tata usaha Negara menjadikan peradilan tata usaha Negara untuk memeriksa, memutuskan, serta menyelesaikan sengketa dimaksud, yang dapat di mulai dari Pengadilan Tata Usaha Negara, Pengadilan Tinggi Tata 
Usaha Negara serta sampai pada Mahkamah Agung apabila pada tingkatan atau jenjang pengadilan ada pihak yang tidak menerima putusan pengadilan pada jenjang yang lebih rendah, dapat mengambil tindakan berupa upaya hukum banding atau kasasi serta peninjauan kembali ke jenjang pengadilan diatasnya. Namun berkaitan dengan substansi penulisan ini maka penulis hanya memfokuskan pembahasan pada upaya hukum banding pada Pengadilan Tinggi Tata Usaha Negara.

Terkait dengan substansi tersebut maka dalam hal putusan yang diambil oleh Pengadilan Tata Usaha Negara sebagai pengadilan tingkat pertama terhadap sengketa Tata Usaha Negara (Keputusan Tata Usaha Negara) ada pihak yang merasa tidak puas terhadap Putusan Pengadilan Tata Usaha Negara tersebut dapat melakukan upaya hukum banding ke Pengadilan Tinggi Tata Usaha Negara guna mencari keadilan atau kepastian hukum terhadap perkara yang dipersengketakan.

Dalam hal pemeriksaan pada tingkat banding, pihak pemohon banding diberikan kesempatan untuk mengajukan argumen-argumennya dalam memori banding mengenai hal-hal yang dianggapnya perlu yang menurutnya telah dilupakan oleh hakim Pengadilan Tata Usaha Negara, serta dapat pula diajukan bukti-bukti baru yang belum pernah diajukan pada tingkat pertama.

Menurut Indroharto, bahwa pemeriksaan dalam tingkat banding itu dimaksudkan agar seluruh pemeriksaan baik mengenai fakta-fakta hukum maupun penarapan hukum serta putusan akhir yang telah dilakukan oleh hakim tingkat pertama di ulang kembali oleh pengadilan tinggi. Pada pemeriksaan tingkat banding para pihak di berikan kesampatan untuk mengajukan argumen-argumennya dalam bentuk memori banding mengenai hal-hal yang dianggapnya perlu yang menurutnya telah dilupakan oleh hakim tingkat pertama.
Dapat pula di situ diajukan bukti-bukti baru yang belum pernah diajukan pada tingkat pertama atau membantah atau memperkuat pertimbangan-pertimbangan maupun putusan dari hakim tingkat pertama. Pemeriksaan tingkat banding itu bersifat devolutif artinya seluruh pemerinsaan perkara dipindahkan dan diulang oleh pengadilan tinggi yang bersangkutan. ${ }^{5}$

Tindakan banding oleh pihak yang tidak puas terhadap putusan Pengadilan Tata Usaha Negara dijamin oleh ketentuan Pasal 122 Undang-Undang Nomor 5 Tahun 1985 yang menyebutkan bahwa :

“Terhadap putusan Pengadilan Tata Usaha Negara dapat dimintakan pemeriksaan banding oleh penggugat atau tergugat kepada Pengadilan Tinggi Tata Usaha Negara".

Pengajuan banding dapat dilakukan oleh pihak yang berkedudukan sebagai penggugat (orang atau badan hukum perdata) maupun tergugat (badan atau pejabat tata usaha Negara). Pada prinsipnya pihak yang mengajukan banding adalah pihak yang tidak menerima putusan Pengadilan Tata Usaha Negara. Artinya bahwa tidak menutup kemungkinan pihak pengugat maupun tergugat dapat menjadi pihak yang berkedudukan sebagai pihak yang mengajukan permohonan banding atau biasa disebut pembanding. Berbeda pada saat perkara tersebut diajukan ke Pengadilan Tata Usaha Negara, dimana yang selalu menjadi pengugat adalah orang atau badan hukum perdata, sedangkan yang menjadi tergugat selalu adalah badan atau pejabat tata usaha Negara.

Pihak yang melakukan upaya hukum banding terhadap perkara yang telah diputuskan oleh Pengadilan Tata Usaha Negara dibatasi oleh waktu untuk

5 Indroharto. (2001). Teori dan Praktek Hukum Acara Peradilan Tata Usaha Negara, Jakarta: Grafindo, h. 223. 
mengajukan banding ke Pengadilan Tinggi Tata Usaha Negara. Hal ini sebagaimana diatur dalam ketentuan Pasal 123 Undang-Undang Nomor 5 Tahun 1986 yang menetapkan waktu untuk dilakukan upaya hukum banding terhadap putusan Pengadilan Tata Usaha Negara adalah 14 hari setelah putuan pengadilan itu diberitahukan kepadanya secara sah. Ketentuan Pasal 123 Undang-Undang Nomor 5 Tahun 1986 secara lengkap menyebutkan bahwa :

(1) Permohonan pemeriksaan banding diajukan secara tertulis oleh pemohon atau kuasanya yang khusus dikuasakan untuk itu kepada Pengadilan Tata Usaha Negara yang menjatuhkan putusan tersebut dalam tenggang waktu empat belas hari setelah putusan Pengadilan itu diberitahukan kepadanya secara sah.

(2) Permohonan pemeriksaan banding disertai pembayaran uang muka biaya perkara banding lebih dahulu, yang besarnya ditaksir oleh Panitera.

Permohonan banding atau memori banding diajukan diajukan oleh pemohan banding secara tertulis kepada Pengadilan Tinggi Tata Usaha Negara melalui Pengadilan Tata Usaha Negara yang telah memeriksa dan memutus perkara dimaksud, yang berisikan hal-hal yang dianggapnya perlu yang menurutnya telah dilupakan oleh hakim Pengadilan Tata Usaha Negara, serta dapat pula diajukan bukti-bukti baru yang belum pernah diajukan pada tingkat Pengadilan Tata Usaha Negara. Permohonan banding yang diajukan dicatat oleh panitera dalam daftar perkara disertai dengan pembayar uang muka biaya perkara serta panitera memberitahukan permohonan banding kepada terbanding.

Selambat-lambatnya 30 (tiga puluh) hari sesudah permohonan pemeriksaan banding dicatat, Panitera memberitahukan kepada kedua belah pihak bahwa mereka dapat melihat berkas perkara di kantor Pengadilan Tata Usaha Negara dalam tenggang waktu 30 (tiga puluh) hari setelah mereka menerima pemberitahuan tersebut, dan dalam waktu 30 (tiga puluh) hari tersebut maka pihak terbanding harus memasukan kotra memori banding, serta para pihak harus menyerahkan surat-surat berkaitan dengan perkara yang disengketakan dan bukti-bukti lainnya kepada panitera Pengadilan Tata Usaha Negara. Penyerahan kontra memori banding serta surat keterangan dan bukti lainnya kepada panitera Pengadilan Tata Usaha Negara sedapat mungkin harus terjadi sebelum berkas perkara yang bersangkutan di kirim ke Pengadilan Tinggi Tata Usaha Negara. ${ }^{6}$

Sebelum permohonan pemeriksaan banding diputus oleh Pengadilan Tinggi Tata Usaha Negara maka permohonan tersebut dapat dicabut kembali oleh pemohon, dan dalam hal permohonan pemeriksaan banding telah dicabut, tidak dapat diajukan lagi meskipun jangka waktu untuk mengajukan permohonan pemeriksaan banding belum lampau.

Namun yang menjadi permasalahan bagi penulis mengenai penetapan waktu untuk mengajukan upaya hukum banding sebagaimana ditetapkan dalam ketentuan Pasal 123 ayat (1) Undang-Undang Nomor 5 Tahun 1986 yang menetapkan bahwa permohonan pemeriksaan banding diajukan secara tertulis oleh pemohon atau kuasanya yang khusus dikuasakan untuk itu kepada Pengadilan Tata Usaha Negara yang menjatuhkan putusan tersebut dalam tenggang waktu empat belas hari setelah putusan Pengadilan itu diberitahukan kepadanya secara sah.

Sesuai ketentuan Pasal 123 ayat (1) Undang-Undang Nomor 5 Tahun 1986 tersebut maka pihak yang tidak puas terhadap putusan Pengadilan Tata Usaha Negara harus mengajukan permohonan

6 Kansil, C.S.T. (1996) Hukum Acara Peradilan Tata Usaha Negara, Jakarta: Pradnya Paramita, h. 176. 
banding ke Pengadilan Tinggi Tata Usaha Negara dalam waktu 14 (empat belas) hari sejak putusan tersebut diberitahukan secara sah. Apabila dalam batas waktu 14 (empat belas) hari pihak yang tidak puas terhadap putusan dimaksud tidak melakukan upaya hukum banding terhadap Putusan Pengadilan Tata Usaha Negara ke Pengadilan Tinggi Tata Usaha Negara maka pihak tersebut tidak dapat melakukan upaya hukum banding terhadap putusan dimaksud dan dianggap telah menerima Putusan Hakim Pengadilan Tata Usaha Negara tersebut.

Namun menurut penulis ketentuan Pasal 123 Undang-Undang Nomor 5 Tahun 1986 tidak memberikan penjelasan mengenai penetapan waktu 14 (empat belas) hari untuk mengajukan banding terhitung sejak putusan itu diucapkan dalam persidangan atau sejak putusan itu diterima oleh pemohon. Penjelasan ketentuan Pasal 123 Ayat Undang-Undang Nomor 5 Tahun 1986 hanya menjelaskan bahwa yang dimaksud dengan "empat belas hari" dalam ayat ini adalah empat belas hari menurut perhitungan tanggal kalender.

Hal ini tentunya menimbulkan penafsiran yang berbeda mengenai kapan dimulainya perhitungan waktu 14 (empat belas) hari tersebut, sebab ketentuan Pasal 123 ayat (1) hanya menyebutkan bahwa permohonan pemeriksaan banding diajukan secara tertulis oleh pemohon atau kuasanya yang khusus dikuasakan untuk itu kepada Pengadilan Tata Usaha Negara yang menjatuhkan putusan tersebut dalam tenggang waktu empat belas hari setelah putusan Pengadilan itu diberitahukan kepadanya secara sah, sehingga menimbulkan pertanyaan oleh penulis bahwa Apakah makna kata diberitahukan secara sah itu terhitung sejak putusan di dibacakan dalam sidang ataukan ketika salinan putusan itu di dapat oleh pemohon.

Dalam ketentuan Pasal 108 ayat (2) Undang-Undang Nomor 5 Tahun 1986 yang menyebutkan bahwa :
"Apabila salah satu pihak atau kedua belah pihak tidak hadir pada waktu putusan Pengadilan diucapkan, atas perintah Hakim Ketua Sidang salinan putusan itu disampaikan dengan surat tercatat kepada yang bersangkutan".

Ketentuan Pasal 108 ayat (2) Undang-Undang Nomor 5 Tahun 1986 tidak ada penjelasan, sehingga menimbulkan permasalahan mengenai perhitungan waktu 14 (empat belas) hari sebagai batas waktu untuk mengajukan banding, yang mana pada saat pembacaan putusan pihak yang mengajukan banding tidak hadir pada persidangan maka apakah perhitungan waktu 14 (empat belas) hari di hitung sejak alinan putusan tersebut tercatat dipengadilan tata usaha Negara untuk mengeluar salinan putusan untuk disampaikan kepada pihak yang tidak hadir pada saat putusan itu dibacakan atau sejak salinan putusan itu diterima oleh pihak yang menerima dan dicatat oleh petugas yang memberikan.

Menurut Indroharto bahwa untuk menghindari keruwetan masalah perhitungan mulai berlakunya tenggang waktu banding, sebaiknya yang dapat dianggap pemberitahuan putusan dengan sah kepada pemohon adalah penyampaian salinan putusan dengan surat tercatat. ${ }^{7}$ Hal ini mengandung pengertian bahwa ketika salinan putusan itu ketika di catat untuk dikirim oleh pengadilan kepada pihak yang tidak hadir dalam persidangan maka mulai terhitung waktu termasuk waktu 14 (empat belas) hari untuk melakukan upaya hukum banding itu.

Namun ada juga dalam praktek perhitungan 14 (empat belas) hari untuk mengajukan upaya hukum banding, mulai terhitung sejak salinan putusan itu diterima oleh pemohon banding yang pada waktu pembacaan putusan tidak hadir dalam persidangan. Artinya ketika

\footnotetext{
7 Indroharto, Op Cit, h. 224.
} 
salinan putusan tersebut dikirim melalui jasa pos dan ketika jasa pos menyampaikan salinan putusan itu kepada pihak yang tidak hadir maka sejak itulah dihitung pemberlakuan waktu 14 (empat belas) hari untuk mengajukan upaya hukum banding oleh pihak yang tidak hadir dalam persidangan pada saat pembacaan putusan.

Tetapi faktanya ada perkara yang dimohonkan banding tidak diterima oleh pengadilan tinggi tata usaha Negara dengan alasan telah melewati batasan waktu 14 (empat bealsa) hari untuk mengajukan upaya hukum banding, Padahal sejak pemohon banding ketika menerima salinan putusan yang dikirim melalui kantor pos, belum melewati waktu 14 (empat belas) hari sejak diterimanya salinan putusan itu.

Hal ini terlihat dari putusan Pengadilan Tinggi Tata Usaha Negara Makassar Nomor 147/B.TUN/2012/PT.TUN.Mks menolak permohonan banding yang diajukan oleh pihak pembanding dengan alasan waktu untuk mengajukan banding telah melawati 14 (empat belas) hari ${ }^{8}$, yang perkara tersebut telah di putuskan Pengadilan Tata Usaha Negara Ambon Nomor 09/G/2012/PTUN.ABN 9 , mengenai sengketa antara CV. WKU, melawan Kepala Dinas Kehutanan Dan Perkebunan Kabupaten Maluku Tengah, yang mengeluarkan Surat Keputusan Kepala Dinas Kehutanan dan Perkebunan Kabupaten Maluku Tengah Nomor 525/54/SK/XII/2011 tanggal 12 Desember 2011 tentang Perubahan atas Surat Keputusan Kepala Dinas Kehutanan dan Perkebunan Kabupaten Maluku Tengah Nomor 522.3/54/2010 tanggal 14 Desember 2010 tentang Sanksi Denda Administratif kepada CV. WKU atas Penebangan pada Areal Izin

\footnotetext{
8 Putusan Pengadilan Tinggi Tata Usaha Negara Makassar Nomor 147/B.TUN/2012/PT.TUN. Mks

9 Putusan Pengadilan Tata Usaha Negara Ambon Nomor 09/G/2012/PTUN.ABN
}

Peruntukan Tanpa Memiliki Izin Pemanfaatan Kayu. ${ }^{10}$

Selain itu, upaya hukum yang dilakukan oleh Pejabat Tata Usaha Negara dalam hal ini Ketua Pemilihan Umum Maluku Kabupaten Maluku Tengah upaya hukum banding tidak diterima oleh Pengadilan Tata Usaha Negara Ambon yang akan dilimpahkan perkaranya di Pengadilan Tinggi Tata Usaha Negara dikarenakan telah melewati waktu yang telah ditentukan oleh Undang-Undang Peradilan Tata Usaha Negara. Dalam Perkara Tata Usaha Negara Nomor 30/G/2014/PTUN.ABN. Pengadilan Tata Usaha Negara Ambon yang memeriksa, memutus dan menyelesaikan sengketa Tata Usaha Negara pada tingkat pertama dengan acara biasa, telah menjatuhkan Putusan sebagai berikut, dalam sengketa antara J.H.S S.Pd, kewarganegaraan Indonesia, pekerjaan Wiraswasta, bertempat tinggal di Desa Morela, Kecamatan Leihitu, Kabupaten Maluku Tengah melawan Ketua Komisi Pemilihan Umum Kabupaten Maluku Tengah, tempat kedudukan di Jalan R.A Kartini Nomor 1 Kota Masohi, Kabupaten Maluku Tengah sebagai Tergugat dan J.G.S, S.Th, kewarganegaraan Indonesia, pekerjaan Anggota DPRD Kabupaten Maluku Tengah, bertempat tinggal di RT. 042 Desa Suli, Kecamatan Salahutu, Kabupaten Maluku Tengah sebagai Tergugat II Intervensi dengan Amar Putusan yang diputuskan tanggal 25 Pebruari 2014 sebagai berikut : ${ }^{11}$

10 Surat Keputusan Kepala Dinas Kehutanan dan Perkebunan Kabupaten Maluku Tengah Nomor 525/54/SK/XII/2011 tanggal 12 Desember 2011 tentang Perubahan atas Surat Keputusan Kepala Dinas Kehutanan dan Perkebunan Kabupaten Maluku Tengah Nomor 522.3/54/2010 tanggal 14 Desember 2010 tentang Sanksi Denda Administratif kepada CV. WKU atas Penebangan pada Areal Izin Peruntukan Tanpa Memiliki Izin Pemanfaatan Kayu.

11 Putusan Pengadilan Tata Usaha Negara Dalam Perkara Nomor 30/G/2014/PTUN.ABN, tanggal 25 Pebruari 2014. 


\section{E N G A D I L I}

Dalam Eksepsi

Menolak Eksepsi Tergugat dan Tergugat II Intervensi untuk seluruhnya

Dalam Pokok Sengketa

1. Menolak gugatan Penggugat untuk seluruhnya

2. Menghukum Penggugat untuk membayar biaya perkara sejumlah

Rp. 432.000,- (Empat ratus tiga puluh dua ribu rupiah)

J.H.S, S.Pd merasa tidak puas dengan putusan Pengadilan Tata Usaha Negara, karena menurutnya akibat keputusan yang dikeluarkan oleh Pejabat Tata Usaha Negara (Ketua Komisi Pemilihan Umum Kabupaten Maluku Tengah telah melanggar peraturan perundang-undangan maupun telah melanggar asas-asas umum pemerintahan yang baik. Merasa tidak puas dengan keputusan Pengadilan Tata Usaha Negara akhirnya mengajukan banding di Pengadilan Tinggi Tata Usaha Negara. Namun pengajuan banding yang diajukan oleh J.H.S, S.Pd tidak diterima dikarenakan sudah melampaui waktu 14 (empat belas hari) yang ditentukan oleh Undang-Undang Peradilan Tata Usaha Negara. Pengadilan Tata Usaha Negara Ambon mengeluarkan Penetapan Pengadilan Tata Usaha Negara Ambon dalam perkara Nomor 30/G/2014/PTUN.ABN tanggal 20 Maret 2014 yang menetapkan sebagai berikut $:^{12}$

1. Putusan Pengadilan Tata Usaha Negara Ambon dalam perkara Nomor : 30/G/2014/PTUN.ABN tanggal 25 Februari 2014 Dalam perkara antara J.H.S, S.Pd, kewarganegaraan Indonesia, pekerjaan Wiraswasta, bertempat

\begin{tabular}{|c|c|c|c|}
\hline 12 & Penetapan & Pengadilan & Tata Usaha \\
\hline Negara & Ambon & Nomor & Nomor \\
\hline
\end{tabular}

tinggal di Desa Morela, Kecamatan Leihitu, Kabupaten Maluku Tengah Dalam hal ini berdasarkan surat kuasa khusus tanggal 22 September 2014 telah memberikan kuasa kepada E.R.S, S.H. dan A.L.U, S.H. Keduanya kewarganegaraan Indonesia, pekerjaan Advokat, beralamat di kantor Advokat S \& Rekan Jln Gandaria, Kampung Pisang (depan rektorat Unpati) Desa Poka, Kecamatan Teluk Ambon Baguala, Kota Ambon sebagai Penggugat melawan Ketua Komisi Pemilihan Umum Kabupaten Maluku Tengah, tempat kedudukan di Jalan R.A Kartini Nomor 1 Kota Masohi, Kabupaten Maluku Tengah dalam hal ini berdasarkan surat kuasa khusus Nomor: 95/KPU.Kab.028.433693/X/2014 tanggal 7 Oktober 2014 telah memberikan kuasa kepada A.N Umum Kabupaten Maluku Tengah, berlamat di Jalan R.A. Kartini Nomor 1 Kota Masohi, Kabupaten Maluku Tengah sebagai Tergugat dengan J.G.S, S.Th., kewarganegaraan Indonesia, pekerjaan Anggota DPRD Kabupaten Maluku Tengah, bertempat tinggal di RT. 042 Desa Suli, Kecamatan Salahutu, Kabupaten Maluku Tengah dalam hal ini berdasarkan surat kuasa khusus tertanggal 14 Oktober 2014 telah memberikan kuasa kepada Y.Y.B, S.H. dan C.B.L, S.H., M.H. Keduanya kewarganegaraan Indonesia, pekerjaan Advokat dan Penasehat Hukum, beralamat di jalan Karang Panjang, RT.002/RW.003, Kelurahan Karang Panjang, Kecamatan Sirimau - Kota Ambon sebagai Tergugat II

2. Surat Permohonan Banding dari Penggugat/Pembanding tertanggal 20 Maret 2014 


\section{Berkas perkara tersebut}

Menimbang, bahwa terhadap Permohonan Banding tersebut, Pengadilan Tata Usaha Negara Ambon perlu mengambil sikap atas permohonan banding tersebut.

Tentang Pertimbangan Hukum :

Menimbang, bahwa ternyata Penggugat/Pembanding telah mengajukan permohonan perkara Banding sebagaimana suratnya tertanggal 20 Maret 2014 terhadap perkara Nomor : 30/G/2014/PTUN.ABN yang terdaftar dalam Register Banding Pengadilan Tata Usaha Negara Ambon

Menimbang, bahwa perkara Nomor : 30/G/2015/PTUN.ABN yang dimohonkan banding oleh Penggugat/Pembanding telah melewati tenggang waktu untuk mengajukan banding, sehingga permohonan Banding tersebut adalah tidak sesuai dengan ketentuan Pasal 123 Undang-Undang Nomor 51 Tahun 2009 tentang Peradilan Tata Usaha Negara yang berbunyi sebagai berikut :

"Permohonan pemeriksaan banding diajukan secara tertulis oleh pemohon atau kuasanya yang khusus dikuasakan untuk itu kepada Pengadilan Tata Usaha Negara yang menjatuhkan putusan tersebut dalam tenggang waktu empat belas hari setelah putusan Pengadilan itu diberitahukan kepadanya secara sah".

Menimbang, bahwa berdasarkan pertimbangan hukum tersebut diatas, cukup beralasan hukum untuk tidak menerima permohonan Banding yang diajukan Kuasa hukum Penggugat/Pembanding tanggal 20 Maret 2014 terhadap perkara Nomor : 30/G/2014/PTUN.ABN

Menimbang, bahwa oleh karena perkara tersebut tidak diterima untuk dimohonkan banding, maka dengan demikian kelanjutan proses pemeriksaan atas perkaranya harus dihentikan dan kepada Panitera Pengadilan Tata Usaha Negara Ambon, diperintahkan untuk mencoret permohonan Bandingnya dari buku Register Perkara Nomor : 30/G/2014/PTUN.

Menimbang, bahwa oleh karena permohonan Banding tersebut tidak diterima untuk dimohonkan banding, maka kepada Penggugat/Pembanding dihukum untuk membayar biaya perkara yang timbul, yang akan ditetapkan dalam amar penetapan ini

Mengingat, Pasal 123 Undang-Undang Nomor 5 Tahun 1986 sebagaimana telah diubah dengan Undang-Undang Nomor 9 Tahun 2004 dan Undang-Undang Nomor 51 Tahun 2009 Tentang Peradilan Tata Usaha Negara, serta ketentuan peraturan perundang-undangan lain yang terkait.

\section{E N E T A P K A N}

1) Menyatakan Permohonan Banding yang diajukan oleh Pembanding yaitu J.H.S, S.Pd terhadap Putusan Pengadilan Tata Usaha Negara Ambon Nomor : 30/G/2014/PTUN.ABN tidak dapat diterima

2) Menyatakan perkara Banding Nomor : 30/G/2014/PTUN.ABN tidak perlu dikirim

3) Memerintahkan kepada Panitera Pengadilan Tata Usaha Negara Ambon untuk mencoret perkara tersebut dari register Banding Nomor 30/G/2014/PTUN.ABN

4) Menghukum

Penggugat/Pembanding untuk membayar biaya perkara sebesar Rp. 311.000,- (Tiga ratus sebelas ribu rupiah);

Berdasarkan permasalahan yang terjadi tersebut maka menurut penulis menunjukan bahwa makna kata diberitahukan secara sah dalam ketentuan 
Pasal 123 ayat (1) Undang-Undang Nomor 5 Tahun 1986 tidak dapat dimaknai sejak diterima salinan putusan yang tercatat pada resih penerimaan pada kontor pos. Dengan demikian maka pengaturan menyangkut penetapan waktu untuk mengajukan banding khususnya ketika pemohon banding tidak hadir dalam persidangan pada saat pembacaan putusan yang nantinya dimohonkan banding oleh pihak tersebut menimbulkan permasalahan dalam kesatuan penerapan.

\section{Efektitas Penerapan Penetapan Waktu Banding Terhadap Putusan Pengadilan Tata Usaha Negara Pada Wilayah Kepulauan}

Ketentuan Pasal 123

Undang-Undang Nomor 5 Tahun 1986 menetapkan pemohon atau kuasanya dalam tenggang waktu 14 (empat belas) hari setelah putusan pengadilan itu diberitahukan kepadanya secara sah dapat mengajukan banding ke Pengadilan Tinggi Tata Usaha Negara untuk memeriksa perkara yang telah diputuskan oleh Pengadilan Tata Usaha Negara, namun menurut penulis penetapan waktu ini tidak efektif diterapkan pada seluruh daerah khususnya pada daerah yang berkarakteristik kepulauan seperti daerah Provinsi Maluku yang fisik kewilayahan terdiri dari pulau-pulau yang terpisah oleh lautan. Berbeda dengan daerah yang berkarakteristik Kontinental, yang mana wilayah darat yang lebih besar dari wilayah laut bahkan pada daerah continental tidak ada sama sekali wilayah laut sehingga dalam mobilisasi atau perpindahan dari suatu tempat ke tempat yang lain agak muda tidak sesulit seperti daerah yang berkarakteristik kepulauan.

Provinsi Maluku merupakan daerah kepulauan yang memiliki jumlah pulau kurang lebih 559 pulau dan dikelilingi oleh lautan yang luas. Kondisi demikian sangat berpengaruh terhadap aktifitas mobilisasi atau perpindahan dari suatu pulau atau daerah yang satu ke pulau atau daerah yang lainnya, yang mana sarana transportasi utama yang digunakan untuk menghubungkan pulau yang satu dengan pulau yang lain termasuk pulau yang dijadikan sebagai pusat pemerintahan adalah sarana transportasi laut berupa kapal motor laut disamping sarana transportasi lain berupa pesawat udara. Namun secara umum pada daerah kepulauan sarana transportasi laut berupa kapal motor laut yang selalu digunakan untuk memobilisasi atau perpindahan baik orang atau barang dari satu pulau ke pulau yang lain termasuk ke pulau yang menjadi pusat pemerintahan di daerah provinsi maupun ke pusat pemerintahan daerah kabupaten/kota dalam Provinsi Maluku.

Sarana trasnportasi kapal motor laut yang digunakan untuk memobilisasi perpindahan dari satu pulau-ke pulau yang lain ini terkadang tidak dilakukan secara rutinitas atau dapat dikatakan bahwa operasionalnya tidak dilakukan setiap hari apalagi pada daerah-daerah kabupaten yang sangat jauh dengan pusat pemerintahan daerah provinsi Maluku yaitu kota Ambon menujuh atau sebalik dengan daerah-daerah seperti Kabupaten Kepulauan Aru, atau Kabupaten Maluku Tenggara Barat atau Kabupaten Maluku Barat Daya atau sebaliknya dari daerah-daerah tersebut ke Kota Ambon, yang mana kita ketahui bahwa operasinalnya sarana transportasi kapal motor laut dari pulau ambon menuju Kabupaten Kepulauan Aru, atau Kabupaten Maluku Tenggara Barat atau Kabupaten Maluku Barat Daya dalam 1 minggu hanya dilakukan 1 kali, atau sebaliknya dari Kabupaten Kepulauan Aru, atau Kabupaten Maluku Tenggara Barat atau Kabupaten Maluku Barat Daya menuju kota Ambon.

Demikian juga kondisi alam (musim) atau musim gelombang yang biasa terjadi di Provinsi Maluku turut berdampak bagi aktifitas perhubungan laut antar masing-masing pulau, bahkan 
ketika musim golombang terjadi maka sarana transportasi laut yang menghubungkan pulua-pulau tidak diopesaional sama sekali. Kondisi demikian tentunya sangat berdampak besar terhadap waktu pelaksanaan upaya hukum banding apabila pemohon banding yang pada saat pembacaan putusan tidak hadir dalam persidangan, dan yang bersangkutan berkediaman didaerah-daerah seperti daerah Kabupaten Kepulauan Aru, atau Kabupaten Maluku Tenggara Barat atau Kabupaten Maluku Barat Daya, dan ketika menerima salinan putusan, yang bersangkutan tidak puas atau tidak menerima putusan tersebut dan akan mengajukan upaya hukum banding di pengadilan tata usaha Negara yang berada di kota Ambon.

$$
\text { Kondisi demikian sangat }
$$

berdampak pada penetapan waktu 14 hari sebagai batasan waktu untuk melakukan upaya hukum banding apalagi kondisi alam pada saat tidak menghabat mobilisasi atau perpindahan yang akan memohonkan banding ke pengadilan tata usaha Negara karena tidak tersedianya transportasi. Meskipun dalam praktek ada hakim pengadilan tinggi tata usaha Negara menggunakan perhitungan waktu 14 (empat belas) tersebut terhitung sejak salinan putusan itu diterima oleh pihak yang akan memohon banding.

Namun bagi penulis meskipun Hakim Pengadilan Tinggi Tata Usaha Negara menggunakan pendekatan waktu 14 (empat belas) hari untuk mengajukan upaya hukum banding dihitung sejak diterimanya salinan putusan oleh pihak yang memohonkan banding, tetapi menjadi persoalan adalah ketika pihak yang akan memohonkan banding menerima salinan putusan tersebut berada di tempat tinggalnya, yang membutuhkan waktu berhari-hari bahkan minggu untuk sampai pada pengadilan tata usaha Negara untuk mengajukan permohonan banding, bahkan biasa lebih dari waktu 14 (empat belas) hari, apabila harus menunggu lagi jadwal atau rute sarana tansportasi laut (kapal motor laut) yang akan sampai pada tempat dimana yang bersangkutan bertempat tinggal.

Sebagai contoh misalnya pihak yang akan memohonkan bading bertempat tinggal di salah satu tempat pada daerah Kabupaten Kepulauan Aru, atau Kabupaten Maluku Tenggara Barat atau Kabupaten Maluku Barat Daya, yang mana dari daerah-daerah sebagaimana disebutkan diatas, untuk sampai pada daerah kota Ambon membutuhkan waktu kurang lebih satu minggu, ditambah lagi dengan kondisi laut yang bergelombang, dan bahkan biasanya pada waktu-waktu tertentu dalam hal ini musim gelombang ada larangan untuk berpergian dengan mengunakan sarana transportasi laut (kapal motor), ditambah lagi dengan tidak adanya sarana transportasi udara (pesawat udara) yang tidak tersedia di tempat tinggal pihak yang akan memohonkan banding tersebut. Hal ini tentunya sangat berdampak pada keefektifan penetapan waktu 14 (empat belas) hari sebagai batas waktu untuk mengajukan upaya hukum banding khususnya bagi daerah-daerah yang berkarakteristik kepulauan seperti di daerah Provinsi Maluku.

Kondisi demikian akan berdampak pada keterbatasan waktu 14 (empat belas) hari yang ditetapkan untuk mengajukan upaya hukum banding oleh pihak yang tidak puas atau tidak menerima putusan pengadilan Pengadilan Tata Usaha Negara, yang pada waktu pembacaan putusan tersebut pemohon banding tidak hadir dalam persidangan. Hal ini tentunya berkonsekwensi terhadap keterlembatan waktu bagi pihak pemohon untuk melakukan upaya hukum banding, karena rentang kendala dengan pembatasan limit waktu 14 (empat belas) hari. Bahkan penetapan waktu perhitungan empat belas hari untuk diajukan permohonan banding ini, menurut Indrohato, bahwa bagi pemohon yang berada di kepulauan yang terpencil akan sangat dinilai sempit 
waktunya. $^{13}$

Menurut penulis bahwa penetapan waktu 14 (empat belas) hari sebagai limit waktu yang ditetapkan oleh ketentuan Pasal 123 ayat (1) Undang-Undang Nomor 5 Tahun 1986 untuk diajukan permohonan banding dirasakan waktunya tidak efaktif untuk diterapkan pada daerah yang berkarakteristik kepulauan. Limit waktu 14 (empat belas) tentunya sangat efektif untuk diterapkan pada daerah yang karakteristik kontinental yang hanya membutuhkan transportasi darat (mobil) untuk samapai ket tempat dimana pemohon banding berada ke pengadilan tempat untuk megajukan permohonan banding. Tetapi tidak efektif diterapkan bagi daerah yang berkarakteristik kepuluan seperti di Proviinsi Maluku.

Dengan demikian menurut penulis penetapan waktu 14 (empat belas) hari sejak salinan putusan diberitahukan secara sah kepada pemohon untuk diajukannya upaya hukum banding terhadap putusan pengadilan tata usaha negara dianggap tidak efektif untuk di terapkan di daerah yang berkarakteristik kepulauan, yang mana kondisi perhubungan serta kondisi alam (musim) sangat berpengarauh terhadap mobilisasi pihak yang akan memohonkan banding menuju ke pulau yang menjadi daerah tempat dimana Pengadilan Tata Usaha Negara itu berada untuk mengajukan upaya hukum banding, apabila pemohon banding pada saat pembacaan putusan pengadilan tidak hadir pada persidangan itu, dan tidak mengetahui mengenai putusan dimaksud.

\section{P E N U T U P}

Penetapan waktu 14 (empat belas) untuk mengajukan permohonan banding bagi pihak tidak puas atau menerima putusan Pengadilan Tata Usaha Negara sebagaimana ditetapkan dalam Ketentuan

13 Wiyono, R. (2008). Hukum Acara Peradilan Tata Usaha Negara, Jakarta: Sinar Grafika, h. 213
Pasal 123 Undang-Undang Nomor 5 Tahun 1986 yang mana pada waktu putusan Pengadilan Tata Usaha Negara dibacakan tidak hadir pada persidangan sebagaimana ditetapkan dalam ketentuan Pasal 108 ayat (2) Undang-Undang Nomor 5 Tahun 1986 dan bertempat tinggal di daerah kepulauan seperti Provinsi Maluku yang memiliki wilayah luat luas dan terdiri dari pulau-pulau, sangat berdampak pada pemenuhan ketepatan waktu yang ditetapkan untuk mengajukan upaya hukum banding. Ketika dalam putusan Pengadilan Tata Usaha Negara pemohon banding tidak hadir pada persidangan, sementara yang bersangkutan bertempat tinggal di daerah kepulauan, yang untuk sampai pada daerah kota Ambon membutuhkan waktu kurang lebih satu minggu, apalagi ditambah dengan kondisi laut yang bergelombang, terdapat larangan untuk berpergian dengan menggunakan sarana transportasi laut serta tidak tersedianya sarana transportasi udara tentunya sangat berdampak pada keefektifan penetapan waktu 14 (empat belas) hari sebagai batas waktu untuk mengajukan upaya hukum banding. Dengan demikian berdasarkan kondisi tersebut maka penetapan waktu 14 (empat belas) hari untuk mengajukan upaya hukum banding tidak efaktif diterapkan bagi daerah yang berkarakteristik kepulauan. Hanya efektif diterapkan pada daerah yang berkarakteristik continental.

\section{DAFTAR PUSTAKA}

Indroharto. (2001). Teori dan Praktek Hukum Acara Peradilan Tata Usaha Negara, Jakarta: Grafindo.I Kansil, C.S.T. (1996) Hukum Acara Peradilan Tata Usaha Negara, Jakarta: Pradnya Paramita.

Nirahua, Salmon E.M. (2013). Hukum Perizinan Pengelolaan Sumber Daya Alam di Wilayah Laut Daerah, 
Jakarta: Raja Grafindo Persada.

Saiyung, (2000). Mencegah Pejabat Tata

Usaha Negara Sebagai Tergugat Dalam PTUN (Analisis Hukum dan Peraturan Perundang-Undangan), Jakarta: Depdagri dan Yayasan Kajian Informasi Perundang-Undangan.

Tjandra, Riawan. (2009). Peradilan Tata Usaha Negara Mendorong Terwujudnya Pemerintah Yang Bersih Dan Berwibawa, Yogyakarta: Universitas Adma Jaya.

Wiyono, R. (2008). Hukum Acara Peradilan Tata Usaha Negara, Jakarta: Sinar Grafika. 